\title{
THE PARADOXES OF CREATIVITY MANAGEMENT
}

\author{
Tomas Kačerauskas
}

\section{Introduction}

Creativity is a very important aspect of market economy. Some scholars (Howkins, 2007; Florida, 2002) are absolutely enthusiastic about creativity that should give a competitive priority in respect of the competitors. Nevertheless, creativity also raises many problems in management of it from feeling of guilty to threat against identity of organization. In general, creativity is an ambivalent and contradictory phenomenon that covers both positive and negative aspects. As a result, management of creativity faces some paradoxes. The main aim of this paper is to describe these paradoxes. Another aim is to present the different approaches towards creativity management. Finally, the paper seeks to dethrone a naive attitude that creativity in economy solves all possible problems. The biggest challenge to the management is the very creativity.

In the first chapter I will present different concepts of creativity and innovation in the perspective of management. In the second chapter I will analyze ten paradoxes of creativity management including one grand and nine minor paradoxes.

\section{Creativity and Innovation in the Perspective of Management}

Some scholars (Pečiulis, 2015; Reimeris, 2016) speak about contemporary society as a creative one. The understanding of creativity has an evolution from the concept of genius to the concept of creative systems (Černevičiūtè, 2014). Creativity has been treated in different ways from the perspectives of different sciences (Barevičiūtè, 2014). Besides this, understandings of creativity depend on different cultural environments (Klimczuk, 2014; Pruskus, 2015). Table 1 shows the definitions of creativity in the context of management. It is an example how certain context changes the understanding of a phenomenon. On the one hand, the intention to manage helps to narrow and understand the phenomenon of creativity. On the other hand, this context like any other presupposes the variety of definitions. The managers treat creativity as a function of work (Amabile, 1998; Arndt et al., 1999; Drazin et al., 1999), of the novel products (Ford \& Gioia, 2000; Amabile, 1988; Zhou \& Shalley, 2010), of social activity (Ford \& Gioia, 2000; Arndt et al., 1999), of divergent thinking and idea generations (Amabile, 1996; Paulus, 2000; Amabile, 1983), of cognition and judgement (Rank et al., 2004; Amabile, 1982; Ford \& Gioia, 2000), of relationship between an individual and his (her) environment (Anderson et al., 2014; Ford \& Gioia, 2000; Drazin et al., 1999).

Table 2 shows the impact of creativity in a micro environment (in an organization). Besides this, the perspective of management supplements the concept of creativity with the specific characteristics. The impact of creativity is not always positive speaking both - about social connections and about individual feelings. The scholars pay attention to the fact that an individual creativity threatens to the social connections (Arndt et al., 1999; Storr, 1972). Additionally, creativity provokes not only a rejection and criticism (Sutton, 2001), but also the conflicts in an organization (Jung \& Lee, 2015). Finally, creativity causes feeling of guilt (Arndt et al., 1999) or can lead to selfdestruction (Storr, 1972). As a result, it could be said that the positive aspects of creativity are inseparable from its negative factors. That is why the scholars speak about the complex interactions (Anderson et al., 2014) of creativity. Another source of complexity is the double nature of creativity that is directed towards the social environment, although it stems as the individual aspirations that in 
Tab. 1: Definitions of creativity in the context of management

\begin{tabular}{l|l}
\multicolumn{1}{c|}{ Description } & \multicolumn{1}{c}{ References } \\
\hline A subjective judgment & Amabile, 1982 \\
\hline The generation of "original and useful ideas" & Amabile, 1983 \\
\hline Idea generation & Amabile, 1996 \\
\hline $\begin{array}{l}\text { A function of the components as follows: expertise, creative-thinking skills, } \\
\text { motivation (intrinsic and extrinsic) }\end{array}$ & Amabile, 1998 \\
\hline $\begin{array}{l}\text { The joint novelty and usefulness of ideas regarding } \\
\text { products, processes and services }\end{array}$ & $\begin{array}{l}\text { Amabile, 1988; } \\
\text { Zhou \& Shalley, 2010 }\end{array}$ \\
\hline $\begin{array}{l}\text { A complex interaction between the individual and his (her) work environment } \\
\text { (organization) }\end{array}$ & Anderson et al., 2014 \\
\hline $\begin{array}{l}\text { Characterized by the creative work as original one, i. e. different from what } \\
\text { others have done; the case of subculture }\end{array}$ & Arndt et al., 1999 \\
\hline $\begin{array}{l}\text { A critical process necessary for individuals, groups and organizations faced } \\
\text { with complex and interdependent work }\end{array}$ & Drazin et al., 1999 \\
\hline A social activity within particular contexts & Ford \& Gioia, 2000 \\
\hline $\begin{array}{l}\text { A multidimensional phenomenon that depends on different processes, an } \\
\text { area of subjective judgment }\end{array}$ & Ford \& Gioia, 2000 \\
\hline $\begin{array}{l}\text { The divergent thinking with the attributes as follows: fluency, flexibility, } \\
\text { originality, and elaboration }\end{array}$ & Paulus, 2000 \\
\hline \begin{tabular}{l} 
Involving primarily intra-individual cognitive processes \\
\hline
\end{tabular} & Rank et al., 2004 \\
\hline
\end{tabular}

turn are inseparable from the social world. It is not enough to say that the organizations need a balance between convergent (logical) and divergent (imaginative) thinking (Basadur \& Hausdorf, 1996; Chen et al., 2015), between search and creativity (Alexander, 1979) or even between creativity and not creativity (Bilton, 2015). The idea of balance or harmony is inseparable from the idea of comfortable climate in an organization. However, the creative decisions are the results of discomfort, stress or crisis and provoke intolerance, anger or ignorance. The social ties in a comfortable organization could be called micro social capital that exterminates a micro creative capital as possibility of the creative ideas. Florida (2002) speaks about the clash between social capital and creative capital. Nevertheless, Florida is not consequent by rising tolerance as one of three Ts (beside technology and talent) characteristic to creative class. Technology and creativity has been interwined but not necessary in a positive way (Kanišauskas, 2016).

On the other hand, the so called harmonic relations often hide an authoritarian management that suppresses any creativity. So the Platonic (to be precise, Pythagorean) idea of harmony is inconsistent with creative dynamics in an organization and could lead to its collapse because of stagnation of the social relations that lead to a deficit of new ideas within it. It is not about a kind of management of creativity - hard one or soft one. Florida (2002) sees only this aspect of management by advocating so called soft management. Sometimes, we need to make very difficult decisions to provoke the creative ideas. Sutton (2001) calls for hiring the persuasive heretics and for fighting between people within an organization. The management of creativity should be creative too. In other words, it should be both unexpected but still having a clear strategy. Greene (2007) speaks about the different war strategies including the area of management. However, the clear managerial strategy does not mean the obtrusion of certain tactical ways. On the contrary, these ways should be open for the experiments even if they lead to the failures. That is why Amabile (1988) and Sutton (2001) suggest rewarding 


\section{Tab. 2: Characteristics and impact of creativity in an organization}

\begin{tabular}{l|l}
\multicolumn{1}{c|}{ Characteristics } & \multicolumn{1}{c}{ References } \\
\hline $\begin{array}{l}\text { An effective generation process combines both search and creativity within } \\
\text { a context that balances both }\end{array}$ & Alexander, 1979 \\
\hline Communication of ideas as part of creative processes & $\begin{array}{l}\text { Amabile, 1996; } \\
\text { Gilson, 2001 }\end{array}$ \\
\hline Threatening social connection; feelings of guilt & Arndt et al., 1999 \\
\hline Creativity in organization and divergent/convergent thinking & $\begin{array}{l}\text { Basadur \& Hausdorf, } \\
1996\end{array}$ \\
\hline $\begin{array}{l}\text { Dialectics of creativity and not creativity; 'not creativity' as a "necessary } \\
\text { ballast“ }\end{array}$ & Bilton, 2015 \\
\hline $\begin{array}{l}\text { Divergent thinking as generating the ideas, imagination, and non-linear } \\
\text { thoughts }\end{array}$ & Chen et al., 2015 \\
\hline $\begin{array}{l}\text { Socializing as a positive factor for such aspects of creativity as a freer flow of } \\
\text { ideas, more brainstorming, and friendlier work environment }\end{array}$ & Gilson \& Shalley, 2004 \\
\hline Creativity as "the combination of relationship conflict and the relational self" & Jung \& Lee, 2015, p. 45 \\
\hline $\begin{array}{l}\text { The irrational drive necessary to creative work can lead to the narcissistic, } \\
\text { anti-social or self-destructive behavior }\end{array}$ & Storr, 1972 \\
\hline Rejection and criticism towards creative people confident in their work & Sutton, 2001 \\
\hline
\end{tabular}

even the failure by reserving punishment only for inaction. Often, inaction or imitation of work is a result of authoritarian pressure towards the tactical ways that are not open to the workers. In general, managerial culture should be rich (with clear strategy and open tactics) and diverse (soft and hard) enough in order to supports a constant contest for the new winning ideas. The environment of creativity is rather a climax of worry and competition or even fighting instead of harmony and tolerance that often hide authoritarian management and inaction. A harmony should be a task but not reality within a multi-colored work group. Not by accident, the scholars (Stahl et al., 2009; Gilson \& Shalley, 2004; Staw, 1990) stress that the most productive working groups consist of the inconsistent members in different senses. What concerns reality in such creative environment, the most real things are the innovative ideas to be implemented because of the fact that they change the social (economic) order.

Table 3 shows the peculiarities of innovation in the perspective of management. Creativity is a very broad concept used to describe very different human activities, first of all art and generation of ideas not necessary to be implemented. On the contrary, innovation deals with the idea implementation (Amabile, 1996; Kazanjian et al., 2000; Lane \& Lup, 2015; Bledow et al., 2009; West, 2002) or idea application (Bilton, 2015). Being such, the innovation is a more social process comparing with more or less individual creativity. It appeals both to a collective creativity and to job relationship within an organization. As a result, the innovation is not such a vague object of management as creativity. In other words, the management of innovation could be a model of management of creativity. Speaking about management of creativity, many scholars have in mind namely the innovation, i.e. the applied creativity.

\section{Management of Creativity}

Management of creativity covers the different managerial practices including challenge, freedom, resources, work-group features, supervisory encouragement and organizational support (Amabile, 1998). According to some scholars (West, 1990), the management of creativity presupposes a social environment of a team and its factors such as rise of vision, participative safety, task orientation, and support for innovation. However, creativity appeals to an individual activity or a tension between the 
Tab. 3: Definition of innovation in the context of management

\begin{tabular}{l|l}
\multicolumn{1}{c|}{ Characteristics } & \multicolumn{1}{c}{ References } \\
\hline Represents inter-individual social processes in the workplace & Rank et al., 2004 \\
\hline Idea implementation & Amabile, 1996 \\
\hline $\begin{array}{l}\text { The "application of a creative idea, typically towards new products, } \\
\text { new business models or management processes." }\end{array}$ & Bilton, 2015, p. 154-155 \\
\hline Entrepreneurial innovation as a destructive process & Schumpeter, 1939 \\
\hline Novelty plus value & Bilton, 2015, p. 157 \\
\hline Implementation effectiveness & Kazanjian et al., 2000 \\
\hline Useful creative ideas after the process of their successful implementation & Lane \& Lup, 2015 \\
\hline Implementation but not just idea generation & $\begin{array}{l}\text { Bledow et al., 2009; } \\
\text { West, 2002 }\end{array}$ \\
\hline
\end{tabular}

individual aspirations and the tasks of a team. That is why first of all a question arises how to harmonize a principle of management and a principle of creativity. Speaking about creativity, we face indetermination and uncertainty that could be compared with chaos. Additionally, creativity brakes status quo including social relations within an organization, provokes the conflicts and feeling of guilt as we have seen in the previous chapter. Finally, creativity opens the unstable and unclear future for the organization. It seems that the cost is too big for a more or less successful organization with the stable income. It is not strange that most of managers do not tolerate any manifestation of creativity that have associated with a revolution against them personally and against welfare of their organizations. In this sense, the innovation has better prestige than creativity while the first could be better combined with managerial practices. Here, we face another definition of the innovation as creativity under control or a compromise of chaotic creativity. On the other hand, we can speak about fashion or even mania of innovation routinized in a managerial way. As a result, some scholars speak about managerial orthodoxy as about "dogmatic belief in the power of innovation" (Johnsen, 2015, p. 63).

The aporia or paradox of creativity management is as follows: „the employees should systematically follow the instructions of their managers. However, this prescription fosters conformity rather than sparking new initiatives“ (Johnsen, 2015, p. 63). In other words, creativity management is a self- contradiction since management should control and reduce the chaos associated with creativity. By stimulating creativity, the managers risk to provoke the disobedience for their instructions including an instruction to develop creativity. We can call this contradiction the major or grand paradox of creativity management (GP). Having in mind GP, the Hamel's (2007) argument that management can spark innovation is far from being evident.

This paradox is especially sharp in so called hard control that limits any initiative of the employees. Florida (2002) pays attention that the hard control eliminates any creativity in the organization. However, sometimes all the creativity needs is a "hard" decision of the managers, as mentioned above. Additionally, we have the different managerial traditions including paternalistic ones in the different cultural environment around the world (Zhou, 2006). In general, we have the different combinations of hard and soft control in different environments and situations. Similarly, we have the different models of democracy that is strong because of this variety.

Besides this, we have another paradox that could be called the first minor paradox (MP1). Creativity is the most actual during a period of crisis within an organization. On the one hand, successful period of an organization is an obstacle to develop the creative ideas (Bilton \& Cummings, 2014) since the stability and safety has more priority. Routine is an inevitable result of successful present that in turn comes after stormy past period of the creative ideas and their implementation. On the other hand, creativity 
is inseparable from destruction, uncertainty, conflicts or even chaos as mentioned. In other words, any organization should avoid it in order to survive as a whole body. However, one of most important conditions to survive in the competition between the organizations is namely creativity and innovation as its implementation. In general, creativity destroys the status quo relationships both inside an organization (horizontal relationships) and outside it (vertical relationships). The latter ones are not only the existing commercial interests of the sellers (producers) and the consumers (Bilton \& Cummings, 2014), but also the value chains (Bilton, 2007) within a society. In other words, creativity confuses the social order or even cleans the social board for new relationships. It could be compared with the procedure of bracketing in phenomenology: we take the content of our consciesness in the brackets for the sake of new content.

The question of management also asks how to implement the creative ideas - step by step, by using the subtle and incremental changes (Bilton \& Cummings, 2014) or by using the radical decisions with failures and mentioned risks (Sutton, 2011). This leads to a paradox too. It could be called the second minor paradox (MP2) or the paradox of innovation. If we choose a way step by step we avoid the undesirable secondary effects such as conflicts or disorder in the organization but we lose a strategic advantage in respect of the competitors. If we choose a radical way it threatens to the very identity of an organization. It sounds also paradoxically, but the situation of an organization should be really bad in order to take the radical decisions. And vice versa, the biggest obstacles towards the innovations are the good results of the organization.

The third minor paradox (MP3) of creativity management is as follows: by increasing creativity in an organization we increase the probability of the conflict, disorder and disharmony within it. Often a microsocial conflict in an organization follows from the situation when "a minority in the team publicly opposes the beliefs, attitudes, ideas, procedures, or policies assumed by the majority of the team" (McLeod et al., 1997). According to Lane and Lup (2015), tensions and contradictions in managing of creativity lead to organizational success. Additionally, the structural solutions could be evaluated as a way to split and place the contradictory tasks (ibid). As mentioned, creativity destroys the status quo. Although some scholars (Bilton \& Cummings, 2014) openly call for such destroy in order to form new environment, it does not guarantee any new order. Even in the case of successful innovation the success could be (and usually is) an apple of discord. We can remember the peripeteias of S. Jobs' career in Apple Company. In general, creativity management is inseparable from conflict management (Gelfand et al., 2008; Hoever et al., 2012; Tekleab \& Quigley, 2014; Nijstad et al., 2014; Jung \& Lee, 2015; Chen et al., 2015). MP3 has one more aspect. On the one hand, there is a need of higher level of creative entrepreneurs' divergent thinking in order to solve the interpersonal conflicts in organization (Chen et al., 2015). On the other hand, the divergent thinking increases the possibility of the conflicts as nothing else. Here, it is not enough to say in unproblematic way that variety of information, skills and points of view exchange ideas while working together presupposes more novel solutions (Staw, 1990). The different versions of such adoration of variety in a team we face in Howkins (2007) and in Florida (2002). If MP1 deals with the structure of an organization and MP2 appeals to the technology of management, MP3 covers the psychological aspects of the creativity agents.

Besides the mentioned issues, we have also the sociological aspects in creativity management. On the one hand, creativity is an individual activity while an outstanding individual demonstrates the original solutions and approach towards the problems. On the other hand, it is a social activity in twofold sense. First, even the most original ideals arise in a social environment as in the background of these outstanding ideas. Any inventor or innovator is not alone both by being educated in one or another way and by working in a team. Second, the product of creativity appeals to certain social environment (market of consuming). We can call the innovation also as socialization of creativity. As a result, we face one more paradox as follows: every inventor or innovator tries to negate his (her) social environment that has educated and stimulated him (her). It could be called forth minor paradox (MP4).

As mentioned, the alternative between hard and soft management is paradoxical, too. 
Actually, creativity needs enough autonomy and does not tolerate any hard control. However, if we have soft control we do not have any creativity, because of its ambivalent nature. It could be said both about individual and social creativity in a team. The history of art shows that almost all masterpieces of art emerge after an artist has the order to create it and certain control of a customer. And vice versa, creativity is impossible without certain freedom of activity and especially without freedom of thinking. The scholars (Oldham \& Cummings, 1996; Zhou, 1998) stress job autonomy for experimenting and exploring alternative ideas. Sutton (2001) speaks about management of freedom and gives an example of free idea generation on Frydays at Coming's Sullivan Park R\&D lab. As a result of this Fryday freedom, we have invented genomics-technology "that was officially killed by the head of research but was pursued in Fryday afternoon experiments." (Sutton, 2001, p. 100) A kind of hard control is the hierarchical control that presupposes the presence of an authority figure. Usually, it makes a negative impact on idea generation (Mullen, 1991). According to Shalley and Gilson (2004), the hierarchical organizational structures might discourage employees from taking creative approaches to their work. Lane and Lup (2015) call it "mimicria of autocratic government". If we remember Plato (1992) any autocracy or tyranny finally leads to a revolution, disorder and anarchy. We notice it in different contemporary regimes around the world. Usually, a development of the ideas in the frame of a scientific or artistic school is also a kind of safe but constricted activity in respect of novelty. We should always choose between obedience to our school and creative freedom that threatens the sanctions of this school. Not by accident, the most prominent artists have been either outside any school (such as V. van Gogh or M. K. Čiurlionis) or the fathers of them (such as Picasso or S. Dali). Nevertheless, it is already mentioned that the implementation of the creative ideas needs sometimes very hard decisions. This paradox of hard/soft management also follows from GP and could be called the fifth minor paradox (MP5).

Additionally, we face the paradox of negative feedback that is positively associated with creative managerial decisions (Ford \& Gioia, 2000). In other words, the worse are the results the more creative are the decisions in organization. To be more precise, such decisions should be because of the fact that the decisions of the managers have been influenced by many factors. Some of them (for example, the authoritative management) simply block creativity. However, even the deficit of creativity in management could be a challenge for changes both in micro-environment of organization and in ways of management. This paradox could be called sixth minor paradox (MP6).

The seventh minor paradox (MP7) deals with relationship between quantity and quality. On the one hand, we need quantity in order to develop creative quality. On the other hand, the quantity negates the quality. We can speak about this dialectics not only in respect of production, but also in respect of the employees and even of the managers. Should we manage the quantity or quality? For example, Sutton (2001) believes that namely quantity should be managed since quality stems from the latter.

The eighth minor paradox (MP8) is about relationship between knowledge and ignorance (naiveté). It seems that the knowledge is the base of any creativity. Sutton appeals to a company's knowledge in order to "see old problems in new ways" and to "break from the past" (2001, p. 96). However, the knowledge of past success does not allow any new approach towards the future. That is why we need not as much knowledge as naiveté or even ignorance in order to "see-and perhaps solve-problems from a new perspective" (Sutton, 2001, p. 99). In a broader context, Kuhn (1996) speaks about the scientific revolutions implemented either by the young scientists or by the scientist from other areas. In other cases, they are enough naive and ignorant, i.e. not ballasted by traditional scientific approach, to see the new ways. As a result, the companies need not only management of knowledge, but also management of ignorance and naiveté. Speaking about the opposition of wisdom and foolishness in organization, Izak (2013) appeals namely to MP8.

Last but not least, we have the paradox of time in creativity management. The scholars speak about the contrast between "the possible future ('what could be') and the present condition ('what is')" (Johnsen, 2015, p. 64), as well about yesterday's success that becomes the "today's chronic malady in organizations" (Johnsen, 2015 , p. 62). That is why the scholars suggest a planning of any activity in an organization. 
However, the planning leads to other paradox since creativity has usually been treated as unexpected and spontaneous activity. Nevertheless, the scholars discuss about the influence of such planning skills as penetration and forecasting on creative thought (Osburn \& Mumford, 2006, p. 173). Additionally, the planning could be treated as a creative, i. e. inherently generative activity involving the mental simulation of future actions (Anzai, 1984; Mumford et al., 2002; Noice, 1991). According to Osburn and Mumford, "planning may contribute to creative thought through at least three mechanisms: (a) promoting idea refinement, (b) promoting opportunistic exploitation of emergent opportunities, and (c) stimulating the generation of new ideas and approaches in an attempt to overcome anticipated problems" (Osburn \& Mumford, 2006, p. 174). Nevertheless, the paradox of time could be deepened by appealing to Heidegger (1996) who speaks about our being towards death. Rephrasing M. Heidegger, all that makes us creative is our possible future collapse. The managers should forget the past success of organization and think about future end of it. In other words, the future death of organization makes the employees alive within it. The paradox of time in management could be called the ninth minor paradox (MP9).
Table 5 shows the specification of all mentioned paradoxes. However, the paradoxes are intertwined with each other. In other words, they walk not alone. For example, Jung and Lee (2015) appeal to the past relationship conflict for the sake of creativity. This argument covers MP3 and MP9. The discussions about organizational ambidexterity and its ingredients such as discipline, stretch, support and trust (Gibson \& Birkinshaw, 2004; Lane \& Lup, 2015) appeal to MP4 and MP5. The argument of Sutton (2001) that the managers should hire the persuasive heretics in order to increase the creative conflicts within organization appeals to MP3 and MP8.

\section{Conclusions}

Management of creativity leads to the different paradoxes that could be classified into one grand and nine minor paradoxes. The grand paradox (GP) is about the contradiction between the principle of management and creativity in general. Usually, any management reduces creativity since it requires following the rules of an organization, i.e. to obey the work routine that is inconsistent with creativity. In the case of creativity stimulation, the managers risk to provoke the disobedience for their instructions including an instruction to develop creativity. The minor paradoxes follow from GP and cover

\section{Tab. 4: The paradoxes of creativity management}

\begin{tabular}{|c|c|}
\hline Paradox & Description \\
\hline GP & $\begin{array}{l}\text { By stimulating creativity, the managers risk to provoke the disobedience for their } \\
\text { instructions including an instruction to develop creativity }\end{array}$ \\
\hline MP1 & Successful period of an organization is an obstacle to develop the creative ideas \\
\hline MP2 & A radical implementation of creative ideas threatens the identity of organization \\
\hline MP3 & Creativity provokes the conflicts in organization \\
\hline MP4 & $\begin{array}{l}\text { Every inventor or innovator tries to negate his (her) social environment that has } \\
\text { educated and stimulated him (her) }\end{array}$ \\
\hline MP5 & $\begin{array}{l}\text { Although hard management kills creativity, the latter needs sometimes very hard } \\
\text { decisions }\end{array}$ \\
\hline MP6 & The worse the results are, the more creative the decisions in organization are \\
\hline MP7 & Organizations should manage both quantity and quality \\
\hline MP8 & $\begin{array}{l}\text { Organization needs not only management of knowledge but also management of } \\
\text { ignorance and naiveté }\end{array}$ \\
\hline MP9 & $\begin{array}{l}\text { The managers should forget the past success of organization and think about future } \\
\text { end of it }\end{array}$ \\
\hline
\end{tabular}


the different aspects of mentioned contradiction including the dangers both of successful past and of identity, the creative conflicts, the social environment, the hard decisions, equilibrium between quantity and quality, ignorance and naiveté, as well as future end of organization. All this shows that creativity generates many additional problems instead of giving only a competitive advantage. As a result, we should refuse naive enthusiasm concerning management of creativity.

\section{References}

Alexander, E. R. (1979). The design of alternatives in organizational contexts: a pilot study. Administrative Science Quarterly, 24(3), 382-404. doi:10.2307/2989919.

Amabile, T. M. (1998). How to kill creativity. Harvard Business Review, 76(5), 76-86.

Amabile, T. M. (1982). Social psychology of creativity: a consensual assessment technique. Journal of Personality and Social Psychology, 43(5), 997-1013. doi:10.1037/00223514.43.5.997.

Amabile, T. M. (1983). Social psychology of creativity: A componential conceptualization. Journal of Personality and Social Psychology, 45(2), 357-376. doi:10.1037/00223514.45.2.357.

Amabile, T. M. (1988). A model of creativity and innovation in organizations. Research in Organizational Behavior, 10, 123-167.

Amabile, T. M. (1996). Creativity in context. Boulder, CO: Westview.

Anderson, N., Potocnik, K., \& Zhou, J. (2014). Innovation and creativity in organizations: A state-of-the-science review, prospective commentary, and guiding framework. Journal of Management, 40(5), 1297-1333. doi:10.1177/0149206314527128.

Anzai, Y. (1984). Cognitive control of real-time event driven systems. Cognitive Science, 8(3), 221-254. doi:10.1016/S03640213(84)80002-6.

Arndt, J., Greenberg, J., Solomon, S. et al. (1999). Creativity and terror management: Evidence that creative activity increases guilt and social projection following mortality salience. Journal of Personality and Social Psychology, 77(1), 19-32. doi:10.1037/00223514.77.1.19.

Barevičiūtè, J. (2014). Pagrindiniai kūrybiškumo ir kūrybingumo aspektai šiuolaikiniuose humanitariniuose bei socialiniuose moksluose [The aspects of creativity and creativeness in contemporary humanities and social sciences]. Filosofija. Sociologija, 25(1), 19-28.

Basadur, M., \& Hausdorf, P. A. (1996). Measuring divergent thinking attitudes related to creative problem solving and innovation management. Creativity Research Journal, 9(1), 21-32. doi:10.1207/s15326934crj0901_3.

Bilton, C., \& Cummings, S. (2014). A framework for creative management and managing creativity. In C. Bilton, \& S. Cummings (Eds.), Handbook of management and creativity (pp. 1-12). Regency: Edward Elgar Publishing.

Bilton, C. (2015). Uncreativity: the shadow side of creativity. International Journal of Cultural Policy, 21(2), 153-167. doi:10.1080/10 286632.2014.892933.

Bilton, C. (2007). Management and creativity: from creative industries to creative management. Oxford: Blackwell.

Bledow, R., Frese, M., Anderson, N., Erez, M., \& Farr, J. (2009). A dialectic perspective on innovation: Conflicting demands, multiple pathways, and ambidexterity. Industrial and Organizational Psychology, 2(3), 305-337. doi:10.1111/j.1754-9434.2009.01154.

Černevičiūtè, J. (2014). Creativity Understandings, Evolution: from Genius to Creative Systems. Santalka: Filosofija, Komunikacija, 22(2), 113-125. doi:10.3846/cpc.2014.10.

Chen, M.-H., Chang, Y.-Y., \& Lo, Y.-H. (2015). Creativity cognitive style, conflict, and career success for creative entrepreneurs. Journal of Business Research, 68(4), 906-910. doi:10.1016/j.jbusres.2014.11.050.

Drazin, R., Glynn, M. A., \& Kazanjian, R. K. (1999). Multilevel theorizing about creativity in organizations: A sense making perspective. Academy of Management Review, 24(2), 286307. doi:10.5465/AMR.1999.1893937.

Florida, R. (2002). The Rise of Creative Class. And how it's transforming work, leisure, community and everyday life. New York: Basic Books.

Ford, C. M., \& Gioia, D. A. (2000). Factors influencing creativity in the domain of managerial decision making. Journal of Management, 26(4), 705-732. doi:10.1177/014920630002600406.

Gelfand, M. J., Leslie, L. M., \& Keller, K. M. (2008). On the etiology of conflict cultures. Research in Organizational Behavior, 28, $137-$ 166. doi:10.1016/j.riob.2008.06.001. 
Gibson, C. B., \& Birkinshaw, J. (2004). The antecedents, consequences, and mediating role of organizational ambidexterity. Academy of Management Journal, 47(2), 209-226. doi:10.2307/20159573.

Gilson, L. L. (2001). Diversity, dissimilarity and creativity: Does group composition or being different enhance or hinder creative performance. Washington: Academy of Management Meetings.

Gilson, L. L., \& Shalley, C. E. (2004). A little creativity goes a long way: An examination of teams' engagement in creative processes. Journal of Management, 30(4), 453-470. doi:10.1016/j.jm.2003.07.001.

Greene, R. (2007). The 33 Strategies of War. New York: Penguin.

Hamel, G. (2007). The future of management. Boston: Harvard Business School Press.

Heidegger, M. (1996). Being and Time. Trans. by J. Stambaugh. New York: State University of New York Press.

Hoever, I. J., van Knippenberg, D., van Ginkel, W. P. et al. (2012). Fostering team creativity: Perspective taking as key to unlocking diversity's potential. Journal of Applied Psychology, 97(5), 982-996. doi:10.1037/ a0029159.

Howkins, J. (2007). The Creative Economy. London: Penguin.

Izak, M. (2013). The foolishness of wisdom: Towards an inclusive approach to wisdom in organization. Scandinavian Journal of Management, 29(1), 108-115. doi:10.1016/j. scaman.2012.07.002.

Johnsen, C. G. (2015). Deconstructing the future of management: Pharmakon, Gary Hamel and the impossibility of invention. Futures, 68(April), 57-66. doi:10.1016/j. futures.2014.05.007.

Jung, E. J., \& Lee, S. (2015). The combined effects of relationship conflict and the relational self on creativity. Organizational Behavior and Human Decision Processes, 130(September), 44-57. doi:10.1016/j.obhdp.2015.06.006.

Kanišauskas, S. (2016). Creative technologies entrapped by instrumental mind. Filosofija. Sociologija, 27(1), 45-50.

Kazanjian, R. K., Drazin, R., \& Glynn, M. A. (2000). Creativity and technological learning: The roles of organization architecture and crisis in large-scale projects. Journal of Engineering and Technology Management, 17(3-4), 273298. doi:10.1016/S0923-4748(00)00026-6.
Klimczuk, A. (2014). Barriers to the Development of Creative industries in Culturally Diverse Region. Santalka: Filosofija, Komunikacija, 22(2), 145-152. doi:10.3846/ cpc.2014.13.

Kuhn, T. S. (1996). The structure of scientific revolutions. Chicago and London: University of Chicago Press.

Lane, C., \& Lup, D. (2015). Cooking under fire: Managing multilevel tensions between creativity and innovation in haute cuisine. Industry and Innovation, 22(8), 654-676. doi:10.1080/13662716.2015.1113861.

McLeod, P. L., Baron, R. S., Marti, M. W., \& Yoon, K. (1997). The eyes have it: Minority influence in face-to-face and computermediated group discussions. Journal of Applied Psychology, 82(5), 706-718. doi:10.1037/00219010.82.5.706.

Mullen, B. (1991). Group composition, salience, and cognitive representations: The phenomenology of being in a group. Journal of Experimental Social Psychology, 27(4), 297-323. doi:10.1016/0022-1031(91)90028-5.

Mumford, M. D., Schultz, R. A., \& Osburn, H. K. (2002). Planning in organizations: Performance as a multi-level phenomenon. In F. J. Yammarino, \& F. Dansereau (Eds.), Many faces of multi-level issues (pp. 3-65). Oxford: Elsevier.

Nijstad, B. A., Berger-Selman, F., \& De Dreu, C. K. W. (2014). Innovation in top management teams: Minority dissent, transformational leadership, and radical innovations. European Journal of Work and Organizational Psychology, 23(2), 310-322. doi:10.1080/1359432X.2012.734038.

Noice, H. (1991). The role of explanations and plan recognition in the learning of theatrical scripts. Cognitive Science, 15(3), 425-460. doi:10.1016/0364-0213(91)80004-O.

Oldham, G. R., \& Cummings, A. (1996). Employee creativity: Personal and contextual factors at work, Academy of Management Journal, 39(3), 607-634. doi:10.2307/256657.

Osburn, H. K., \& Mumford, M. D. (2006). Creativity and planning: Training interventions to develop creative problem-solving skills. Creativity Research Journal, 18(2), 173-190. doi:10.1207/s15326934crj1802_4.

Paulus, P. B. (2000). Groups, teams, and creativity: The creative potential of ideagenerating groups. Applied Psychology, 49(2), 237-262. doi:10.1111/1464-0597.00013. 
Pečiulis, Ž. (2015). Vienetiškumas ir tiražas - kūrybos visuomenès paradoksas [Paradoxes of the creative society]. Filosofija. Sociologija, 26(1), 81-85.

Plato. (1992). The Republic. Indianapolis: Hackett Publishing Company.

Pruskus, V. (2015). Kūrybingumo panaudojimo gerinant aplinkos kokybę etiniai ir socialiniai kultūriniai aspektai [Ethical and sociocultural aspects of creativity use in improving the quality of the environment]. Filosofija. Sociologija, 26(3), 201-209.

Rank, J., Pace, V. L., \& Frese, M. (2004). Three avenues for future research on creativity, innovation, and initiative. Applied Psychology, 53(4), 518-528. doi:10.1111/j.14640597.2004.00185.x.

Reimeris, R. (2016). Theoretical features of the creative society. Creativity studies, 9(1), 15-24. doi:10.3846/23450479.2015.1088902.

Schumpeter, J. (1939). Business cycles: A theoretical, historical and statistical analysis of the capitalist process. New York: McGraw Hill.

Shalley, C. E., \& Gilson, L. L. (2004). What leaders need to know: A review of social and contextual factors that can foster or hinder creativity. The Leadership Quarterly, 15(1), 3353. doi:10.1016/j.leaqua.2003.12.004.

Stahl, G. K., Maznevski, M. L., Voigt, A., \& Jonsen, K. (2009). Unraveling the effects of cultural diversity in teams: A meta-analysis of research on multicultural work groups. Journal of International Business Studies, 41(4), 690709. doi:10.1057/jibs.2009.85.

Staw, B. M. (1990). An evolutionary approach to creativity and innovation. In M. A. West, \& J. L. Farr (Eds.), Innovation and creativity at work: Psychological and organizational strategies (pp. 287-308). Oxford: John Wiley \& Sons.

Storr, A. (1972). The dynamics of creation. London: Secker and Warburg.
Sutton, R. I. (2001). The weird rules of creativity. Harvard Business Review, 79(8), 94-103.

Tekleab, A. G., \& Quigley, N. R. (2014). Team deep-level diversity, relationship conflict, and team members' affective reactions: A cross-level investigation. Journal of Business Research, 67(3), 394-402. doi:10.1016/j. jbusres.2012.12.022.

West, M. A. (1990). The social psychology of innovation in groups. In M. A. West, \& J. L. Farr (Eds.), Innovation and creativity at work: Psychological and organizational strategies (pp. 309-333). Chichester: Wiley.

West, M. A. (2002). Sparkling fountains or stagnant ponds: An integrative model of creativity and innovation implementation in work groups. Applied Psychology, 51(3), 355-387. doi:10.1111/1464-0597.00951.

Zhou, J. (1998). Feedback valence, feedback style, task autonomy, and achievement orientation: Interactive effects on creative performance. Journal of Applied Psychology, 83(2), 261-276. doi:10.1037/00219010.83.2.261.

Zhou, J., \& Shalley, C. E. (2010). Deepening our understanding of creativity in the workplace: A review of different approaches to creativity research. In S. Zedeck (Ed.), APA handbook of industrial and organizational psychology (pp. 275-302). Washington: American Psychological Association.

Zhou, J. (2006). A model of paternalistic organizational control and group creativity. Research on Managing Groups and Teams, 9, 75-95. doi:10.1016/S1534-0856(06)09004-9.

Prof. Dr. Tomas Kačerauskas, Ph.D. Vilnius Gediminas Technical University Faculty of Creative Industries Department of Philosophy and Communication tomas.kacerauskas@vgtu.It 


\section{Abstract}

\section{THE PARADOXES OF CREATIVITY MANAGEMENT}

\section{Tomas Kačerauskas}

Creativity is a very important aspect of market economy. Creativity is an ambivalent and contradictory phenomenon that covers both positive and negative aspects. As a result, management of creativity faces some paradoxes. The paper deals with 10 paradoxes of creativity management including one grand paradox (GP) and nine minor paradoxes (MP). By stimulating creativity, the managers risk to provoke the disobedience for their instructions including an instruction to develop creativity (GP). Successful period of an organization is an obstacle to develop the creative ideas (MP1). A radical implementation of creative ideas threatens the identity of organization (MP2). Creativity provokes the conflicts in organization (MP3). Every inventor or innovator tries to negate his (her) social environment that has educated and stimulated him (her) (MP4). Although hard management kills creativity, the latter needs sometimes very hard decisions (MP5). The worse the results are, the more creative the decisions in organization are (MP6). Organizations should manage both quantity and quality (MP7). Organization needs not only management of knowledge but also management of ignorance and naiveté (MP8). The managers should forget the past success of organization and think about future end of it (MP9). The main aim of this paper is to describe these paradoxes. Another aim is to present the different approaches towards creativity management. Finally, the paper seeks to dethrone a naive attitude that creativity in economy solves all possible problems. The biggest challenge to the management is the very creativity.

Key Words: Creativity management, paradoxes, conflict, organization, creative economy.

JEL Classification: B5, J5, L2, M1.

DOI: 10.15240/tul/001/2016-4-003 